\title{
NATURAL BYPRODUCTS AS NUTRIENT ADDITIVES FOR OPTIMIZATION OF PROTEIN CONTENT IN DUNALIELLA SALINA Toed CULTURES
}

\author{
Kassem, A.M., Khaleafa, A.F., Shaalan, S.H., and El-Maghrabi, D.M. \\ Botany Department, Faculty of Science, Alexandria University, Alexandria, Egypt.
}

\begin{abstract}
The present paper aims to formulate a byproduct-supplemented medium suitable for the production of large amounts of protein rich Dunaliella salina biomass. Components of the MH basal growth medium were examined for partial replacement by cheese whey, beet molasses, and yeast fermentation liquor. Maximum growth rate was achieved after 8 days of incubation in the presence of $0.4 \%$ fermentation liquor that replaced $3 / 4$ of the weight of all medium components other than $\mathrm{NaCl}$. Interestingly, the presence of fermentation liquor or cheese whey resulted in more than 1.5 and1.4-fold increases, respectively, in algal protein production. By application of three sequential multi-factorial experimental designs, medium composition was further optimized with respect to protein content in Dunaliella cultures. Among medium components, fermentation liquor was the most significant factor that affected the response. Compared to the basal condition, the optimized medium formula resulted in approximately a 1.7-fold increase in the protein content of Dunaliella salina cultures.
\end{abstract}

Key Words: Dunaliella salina, protein, optimization, byproducts.

\section{Introduction}

Animals and plants have always provided the main food sources. However, there have been many efforts to develop a source of protein independent of agricultural land use. The production of single cell protein as food is an active field of research in recent years (Mahasneh, 1997; Schwarz et al, 1995). Microorganisms, as protein producers, have some advantages over plants and animals. These nonconventional sources of food are of great nutritional value due to their high contents of proteins, vitamins and lipids and the general presence of a complete array of all essential amino acids (Thomas, 1984; Riviere, 1977; Boyd, 1973; Peppler, 1968; Dam et al., 1965). Also microorganisms have short generation times and can be easily modified genetically, cultivated in continuous cultures, and grown on raw materials.

The microscopic algae are the primary producers of the organic matter on which all other forms of aquatic life depend in their feeding. Serious attempts have 
been initiated to use mass cultures for some special micro-algae that accumulate interesting products (Parkinson, 1987). Among those, Dunaliella salina seems to be promising for its utilization as a protein source for feeding. Due to lacking of cell walls, biomass of this halo-tolerant green alga is easily and fully digestible by humans and animals (Ben-Amotz and Avron, 1983). Dunaliella protein is similar, in composition, to other common plant proteins such as soybean meal, (Ben-Amotz and Avron, 1980). In addition to protein, Dunaliella salina is known to produce diverse metabolites such as glycerol (Thakur, 2000), carbohydrates (Shirai et al, 1998), $\beta$-carotene (Orset and Young, 2000), hydrocarbons (Park et al, 1998) and other metabolites.

The growth, metabolism and contents of Dunaliella salina cells are responsive to medium composition (Thakur et al, 2000; Yamaoka et al, 1994). The one-variable-at-a-time approach, used frequently to study the effect of culture environmental factors, consumes time and doesn't guarantee reaching the actual optima. Moreover, it ignores the interactive effects among different variables. On the other hand, multi-factorial experimental designs can effectively deal with technology optimization studies (Montgomery, 1991). These statistical techniques are suitable for designing experiments, building models, evaluating the effective factors, and most importantly, searching the optimum conditions of factors for a desirable response.

In this approach, the relative importance of environmental factors affecting the synthesis of protein in Dunaliella salina has been explored and their optimal levels were elucidated.

\section{Materials and Methods Organism}

The experimental strain of Dunaliella salina was obtained from the algal culture collection of Phychological laboratory, Botany Department, Faculty of Science, Alexandria University. The organism was originally collected from the brine water of salty lagoons at El-Mex district, Alexandria, Egypt.

\section{Culturing Conditions}

The MH formula, as described by Loeblich (1982), was used as a basal growth medium. It contains $(\mathrm{g} / \mathrm{l}): \mathrm{NaCl}, 73.125 ; \mathrm{MgCl}_{2} \cdot 6 \mathrm{H}_{2} \mathrm{O}, 1.5 ; \mathrm{MgSO}_{4} .7 \mathrm{H}_{2} \mathrm{O}$, $0.5 ; \mathrm{KCl}, 0.2 ; \mathrm{KNO}_{3}, \mathrm{NaHCO}_{3}, 0.042 ; \mathrm{CaCl}_{2} .2 \mathrm{H}_{2} \mathrm{O}, 0.2$ and $\mathrm{K}_{2} \mathrm{HPO}_{4}, 0.035$. The medium is supplemented by trace elements as described by Johnson et al. (1968). Axenic cultures were grown under aseptic conditions in the basal formula $\mathrm{MH}, 1 / 4$ $\mathrm{MH}$ (components, other than $\mathrm{NaCl}$, were reduced to $1 / 4$ of their weights in the basal formula) or $1 / 4 \mathrm{MH}$ supplemented with indicated byproduct concentrations. The byproducts used in this work included cheese whey (obtained from the Department of Dairy Products, Faculty of Agriculture, Alexandria University), beet molasses and yeast fermentation liquor (obtained from the Starch and Yeast Company, Alexandria, Egypt). Experiments were conducted in $250 \mathrm{ml}$ Erlenmeyer Pyrex flasks, each contained $50-\mathrm{ml}$ medium. Initial $\mathrm{pH}$ was adjusted to 8.0. Cultures were 
grown in an incubator at a temperature of $25 \pm 1^{\circ} \mathrm{C}$ and light of $4000 \mathrm{Lux}$ with regime cycles of $16 \mathrm{~h}$ light and $8 \mathrm{~h}$ dark $/ 24 \mathrm{~h}$.

\section{Growth Parameters}

Growth of Dunaliella salina was estimated based on cell numbers, which were counted using a hemacytometer. Four replicas were taken to get the mean number of cells per $\mathrm{ml}$ culture. The growth rate, $\mathrm{R}$ (number of divisions per day) was calculated from the formula of Robert (1979):

$\mathrm{R}=\left[3.322 /\left(\mathrm{t}_{2}-\mathrm{t}_{1}\right)\right]\left[\log \mathrm{N}_{2} / \mathrm{N}_{1}\right]$

where $t_{1}=$ time at the beginning of the experiment, $t_{2}=$ time at the end of the experiment, $\mathrm{N}_{1}=$ number of cells $/ \mathrm{ml}$ at $\mathrm{t}_{1}, \mathrm{~N}_{2}=$ number of cells $/ \mathrm{ml}$ at $\mathrm{t}_{2}$.

\section{Protein Estimation}

calorimetrically

Total protein content in Dunaliella salina biomass was estimated as described by Hartree (1972).

\section{Experimental designs}

Plackett-Burman design: The most important environmental factors controlling protein synthesis in Dunaliella salina, were elucidated by applying the PlackettBurman experimental design (Plackett and Burman 1946). It is a fraction of a twolevel factorial design and allows the investigation of $n-1$ variables in $n$ experiments. In the present work, seven variables were screened in eight combinations according to the design shown in Table 1 in the Results section. Examined independent variables included $\mathrm{MgCl}_{2} \cdot 6 \mathrm{H}_{2} \mathrm{O}, \mathrm{MgSO}_{4} \cdot 7 \mathrm{H}_{2} \mathrm{O}, \mathrm{KCl}, \mathrm{KNO}_{3}, \mathrm{NaHCO}_{3}, \mathrm{CaCl}_{2} \cdot 2 \mathrm{H}_{2} \mathrm{O}$ and trace elements (treated as a single factor). The + and - are symbols used to indicate the presence or absence of variables, respectively. All trials were performed in duplicates and the average of observations was used as the response. The main effect of each variable was simply calculated as the difference between the average of measurements made at the presence $(+)$ and the average of measurements observed at the absence (-) of that factor. For determination of variable significance, statistical $t$-values for equal unpaired samples were calculated with respect to the observation records.

Two-level factorial design: With respect to protein production by Dunaliella salina, $a$ quick gross picture of the medium components, which are predicted to be essential, was generated by a two-level $\left(2^{\mathrm{n}}\right)$ factorial experimental design (Chatfield, 1975). Each of these variables was examined at a high setting (coded -) and a low setting (coded + ), which are corresponding to the basal level $\pm 50 \%$. Consequently, the experiment included $2^{5}$ or 32 combinations; each trial was performed only once. The arrangement of the experiment, as shown in Table 7, gave the chance for each medium constituent to be evaluated singly and in combination with any other component. The statistical analysis used was an analysis of variance. The three and four interaction sum of squares (SS) were combined and divided by their number to give the residual mean square. The $F$-ratio was calculated by dividing effect SS by the residual mean square. 
Steepest ascent method. Medium components that affected the response significantly were simultaneously optimized by applying a single steepest ascent experiment (Bloor and England, 1991). In this method, relative concentration change units are chosen based on their corresponding effect total figures calculated from the $2^{\mathrm{n}}$ experimental results.

\section{Results and Discussion \\ Growth of Dunaliella salina}

The growth of Dunaliella salina cells on the MH basal medium was monitored at different time intervals. The data graphed in Fig. 1 show that a lag phase of 5 days was required for a sharp exponential phase of biomass production that prolonged for 12 days. Further increase in cell number was observed until the $18^{\text {th }}$ day of incubation and the maximum growth rate (0.671 divisions/day) was achieved after an incubation period of 8 days.

In another preliminary experiment, the nutritive values of some renewable economic byproducts were evaluated as partial medium supplements. Dunaliella salina cells were grown on $1 / 4 \mathrm{MH}$ enriched with $0.4 \%$ concentration of fermentation liquor, cheese whey, or molasses. Basal medium and $1 / 4 \mathrm{MH}$ cultures were used as controls.

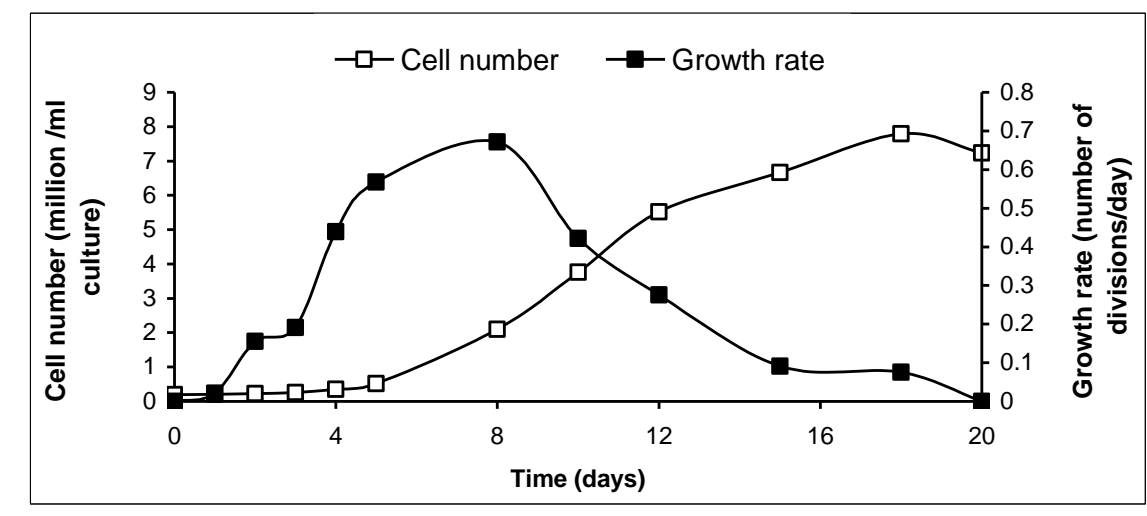

Figure 1: Growth of Dunaliella salina cells on MH basal medium.

The growth was monitored at different time intervals with respect to cell number. As shown in Fig. 2a, all examined nutrient additives dramatically affected algal growth. Highest biomass production results were recorded by the fermentation liquor culture, which clearly exceeded the basal condition, with an exponential growth phase of 18 days. On the other hand, cheese whey and molasses exerted growth inhibitory effects on Dunaliella cultures. As shown in the figure, the inhibitory effect of the later is clearly dramatic. Based on these results, calculations suggested that maximum growth rates in all cultures were achieved at the $8^{\text {th }}$ day. These were $0.431,0.657$, and 0.547 divisions/day in the presence of cheese whey, 
fermentation liquor, and molasses, respectively. Within these 8 days, proteins were maximally synthesized in the fermentation liquor culture with more than $10 \%$ and approximately 53\% increases when compared to the complete basal medium and $1 / 4$ basal medium results, respectively (Fig. 2b). Proteins were also over-produced in the cheese whey culture with approximately $41 \%$ increase when compared to the $1 / 4$ MH control culture. These results coincide with those of other workers who reported that the source and concentration of organic nitrogen source in the culture media causes major changes in the growth and biochemical composition of marine algae, specially protein content (Myklestad and Haug, 1972; Parsons and Takahashi, 1973; Shifrin and Chishlom, 1981).

According to the biomass as well as protein content results of this experiment, fermentation liquor was chosen as an economic nutrient additive in the $1 / 4$ MH for Dunaliella salina.

Elucidation of medium components affecting protein expression by Dunaliella salina

The Plackett and Burman statistical design was applied to determine the degree of significance of medium components as regulators of protein synthesis in Dunaliella salina. Among medium constituents, 7 independent variables; including $\mathrm{MgCl}_{2} \cdot 6 \mathrm{H}_{2} \mathrm{O}, \mathrm{MgSO}_{4} .7 \mathrm{H}_{2} \mathrm{O}, \mathrm{KCl}, \mathrm{KNO}_{3}, \mathrm{NaHCO}_{3}, \mathrm{CaCl}_{2} \cdot 2 \mathrm{H}_{2} \mathrm{O}$ and trace elements; were screened in this experiment. For simplicity, the complex component (trace elements) was treated as a single variable.

Dunaliella salina was cultured under the eight different conditions for 8 days, then cells were analyzed for protein content. The data recorded in Table 1 shows that maximum protein content $(0.285 \mathrm{mg} / \mathrm{ml})$ was achieved at trial 4 where $\mathrm{MgSO}_{4} \cdot 7 \mathrm{H}_{2} \mathrm{O}, \mathrm{KNO}_{3}, \mathrm{NaHCO}_{3}$ and $\mathrm{CaCl}_{2} .2 \mathrm{H}_{2} \mathrm{O}$ were present.

Based on these observations, the main effects and $t$-values were calculated for each independent variable. As shown in Table 2, the significance of examined nutrient elements can be arranged in the following order: $\mathrm{CaCl}_{2} \cdot 2 \mathrm{H}_{2} \mathrm{O}$ (significant), $\mathrm{KNO}_{3}, \quad \mathrm{MgSO}_{4} \cdot 7 \mathrm{H}_{2} \mathrm{O}, \mathrm{KCl}$, trace elements, $\mathrm{NaHCO}_{3}$, and $\mathrm{MgCl}_{2} \cdot 6 \mathrm{H}_{2} \mathrm{O}$. Furthermore, the main effect figures and the signs attributed to them suggest that the effects of trace elements, $\mathrm{NaHCO}_{3}$, and $\mathrm{MgCl}_{2} \cdot 6 \mathrm{H}_{2} \mathrm{O}$ on the production of proteins by Dunaliella salina are slight and negative.

In the complete factorial experiment $\left(2^{\mathrm{n}}\right)$, the workers assumed that insignificant components might be still beneficial, possibly if they are introduced into the medium in other concentrations. Accordingly, factors appeared to be insignificant in the Plackett \& Burman experiment were preferred to be further investigated as a single variable $(\mathrm{M})$ rather than to be excluded from the medium. Examined variables included $\mathrm{M}, \mathrm{CaCl}_{2} \cdot 2 \mathrm{H}_{2} \mathrm{O}$ (the significant variable), and the rest of medium components including fermentation liquor (W), $\mathrm{NaCl}$, and $\mathrm{K}_{2} \mathrm{HPO}_{4}$. Each of these independent variables was examined at two different levels and the experiment was designed according to the $2^{\mathrm{n}}$ standard order shown in Table 3. 


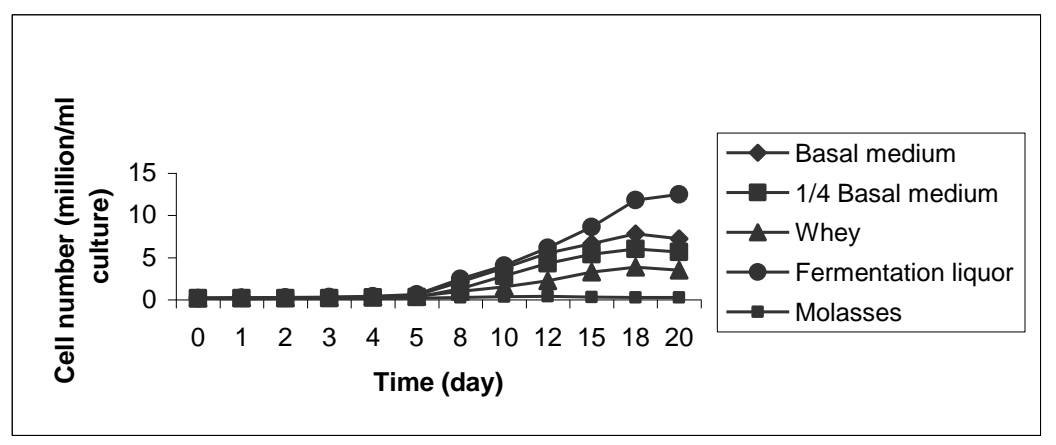

Figure 2a: Growth of Dunaliella salina cultured on basal medium (BM), 1/4 BM or 1/4 BM enriched with $0.4 \%$ whey, fermentation liquor, or molasses.

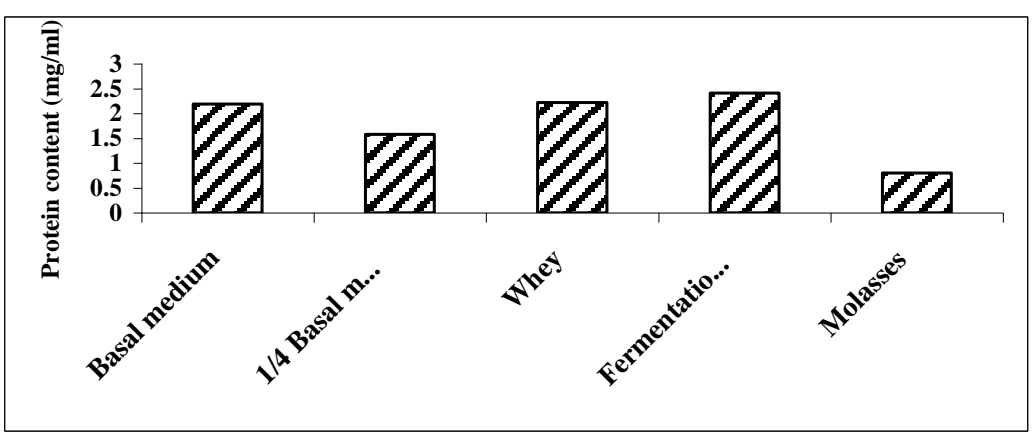

Figure 2b: Protein content of Dunaliella salina grown for 8 days on basal medium, 1/4 BM and $0.4 \%$ concentration of whey, fermentation liquor and molasses in $1 / 4$ basal medium.

Table 1. Plackett-Burman design for 7 factors and experimental results with respect to protein production by Dunaliella salina

\begin{tabular}{|c|c|c|c|c|c|c|c|c|}
\hline \multirow[t]{2}{*}{ Trial } & \multicolumn{7}{|c|}{ Independent variables } & \multirow{2}{*}{$\begin{array}{c}\text { Response } \\
\text { (Mg/ml) }\end{array}$} \\
\hline & $\sum_{0}^{N}$ & 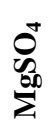 & $\underset{\cup}{\Xi}$ & 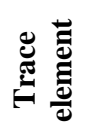 & $\overbrace{}^{\infty}$ & 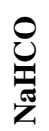 & $\tilde{ల}^{N}$ & \\
\hline 1 & + & + & + & - & + & - & - & 0.259 \\
\hline 2 & + & + & - & + & - & - & + & 0.212 \\
\hline 3 & + & - & + & - & - & + & + & 0.196 \\
\hline 4 & - & + & - & - & + & + & + & 0.285 \\
\hline 5 & + & - & - & + & + & + & - & 0.118 \\
\hline 6 & - & - & + & + & + & - & + & 0.264 \\
\hline 7 & - & + & + & + & - & + & - & 0.144 \\
\hline 8 & - & - & - & - & - & - & - & 0.118 \\
\hline
\end{tabular}


Based on the observations of this experiment and calculations recorded in table 4, it is clear that fermentation liquor (W) was the most significant independent variable (99\% level) that affected protein synthesis in Dunaliella salina. $\mathrm{NaCl}$ was also found to be significant, but to a less extent ( $95 \%$ level). The presented data indicate also that $\mathrm{CaCl}_{2} \cdot 2 \mathrm{H}_{2} \mathrm{O}, \mathrm{K}_{2} \mathrm{HPO}_{4}$ and $\mathrm{M}$ did not affect the response significantly, when each of them is evaluated singly. However, the two-factor interaction calculations suggest that $\mathrm{CaCl}_{2} \cdot 2 \mathrm{H}_{2} \mathrm{O}$ and $\mathrm{M}$ should be considered, as their combined action appeared to have a significant effect on the response. Consequently, $\mathrm{W}, \mathrm{CaCl}_{2} \cdot 2 \mathrm{H}_{2} \mathrm{O}$ and $\mathrm{M}$ were designated as effective variables that require further optimization studies. Due to the positive signs attributed to significant effect total figures, it is also reasonable to predict that the optimum levels of these factors are most likely above their basal levels dictated by the $\mathrm{MH}$ original formula.

\section{Optimization of protein production by Dunaliella salina cultures}

The results obtained from the factorial experiment were used to optimize culture conditions for maximum protein production using the steepest ascent method (Bloor and England, 1991). This experiment contained four independent variables, $\mathrm{W}, \mathrm{NaCl}, \mathrm{CaCl}_{2} \cdot 2 \mathrm{H}_{2} \mathrm{O}$ and $\mathrm{M}$. Due to its insignificant effect in the $2^{\mathrm{n}}$ factorial experiment; $\mathrm{K}_{2} \mathrm{HPO}_{4}$ concentration was treated as a constant, which is introduced to all medium optimization trials at its basal level. Table 5 shows 15 statistically organized medium trials on which Dunaliella salina was cultured for 8 days then analyzed for protein content. The obtained results presented graphically in Fig. 3 proved that the protein content in the Dunaliella cultural trials was gradually increasing and reached maximum at trial number 10 where its record represented approximately $70 \%$ increase when compared to the basal condition. As shown in Table 5, levels of all independent variables in this experiment are increasing as the trial number is going up. This result coincided with the results obtained by Fabergas et al $(1985,1986)$ who found that great variations in protein content have been shown in cultures of different marine microalgae and batch cultures of Dunaliella tertiolecta at relatively high nutrient concentrations. However, a sharp decrease in the protein content was observed on other trials than that of the medium formula number 11. This could be a result of hyper-salinity stress or toxic effect of the heavy metal magnesium when present at high concentrations in the medium (Gerlach et al, 2000; Ford and Mitchell, 1992). 
Table 2. Main effects and $t$-values calculated for each variable based on the observations of the Plackett-Burman experimental design.

\begin{tabular}{|c|c|c|c|c|c|c|c|}
\hline Variable & $\sum_{i=0}^{\infty}$ & $\begin{array}{l}0^{+} \\
\sum^{\infty} \\
\sum\end{array}$ & $\underset{v}{\mho}$ & 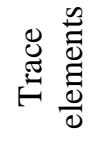 & $\overbrace{}^{m}$ & $\begin{array}{l}0 \\
\substack{T \\
\\
Z}\end{array}$ & $\underbrace{N}_{\tilde{U}}$ \\
\hline Main effect & -0.007 & 0.051 & 0.033 & $-\mathbf{- 0 . 0 3 0}$ & 0.064 & -0.028 & 0.079 \\
\hline$t$-value & -0.140 & 1.133 & 0.660 & -0.600 & 1.422 & -0.540 & 2.051 \\
\hline $\begin{array}{l}\text { Degree of } \\
\text { significance }\end{array}$ & $\begin{array}{c}\text { p>0.1 } \\
\text { n.s. }\end{array}$ & $\begin{array}{c}\text { p }>0.1 \\
\text { n.s. }\end{array}$ & $\begin{array}{c}\text { p }>0.1 \\
\text { n.s. }\end{array}$ & $\begin{array}{c}\text { p>0.1 } \\
\text { n.s. }\end{array}$ & $\begin{array}{c}\text { p>0.1 } \\
\text { n.s. }\end{array}$ & $\begin{array}{c}\text { p>0.1 } \\
\text { n.s. }\end{array}$ & $\begin{array}{c}0.1>p>0.0 \\
5 \\
s\end{array}$ \\
\hline
\end{tabular}

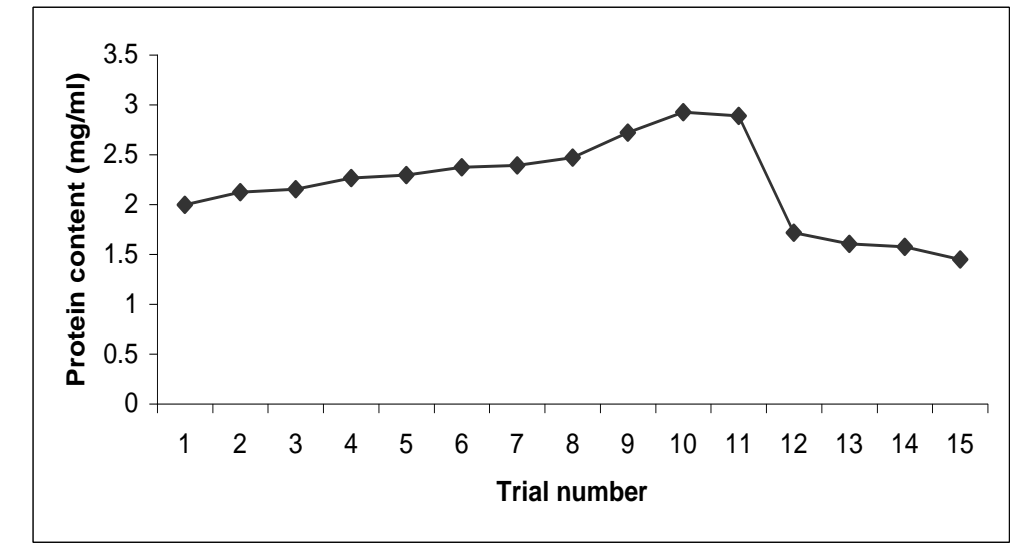

Figure 3: Protein contents in Dunaliella salina cultured (for 8 days) in the proposed trials of the steepest ascent method. 
Natural Byproducts as Nutrient Additives...

Table 3. Arrangement of the five factors under study in a standard orderat the factorial experiment.

\begin{tabular}{|c|c|c|c|c|c|c|}
\hline \multirow[t]{2}{*}{ Trial } & \multirow{2}{*}{$\begin{array}{c}\text { Factor(s) } \\
\text { under study }\end{array}$} & \multicolumn{5}{|c|}{ Factor level } \\
\hline & & $\begin{array}{c}\bar{U} \\
Z\end{array}$ & 3 & $\tilde{U}^{N}$ & 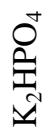 & $\Sigma$ \\
\hline 1 & Base & - & - & - & - & - \\
\hline 2 & $\mathrm{NaCl}$ & + & - & - & - & - \\
\hline 3 & $\mathrm{~W}$ & - & + & - & - & - \\
\hline 4 & $\mathrm{NaCl}, \mathrm{W}$ & + & + & - & - & - \\
\hline 5 & $\mathrm{CaCl}_{2}$ & - & - & + & - & - \\
\hline 6 & $\mathrm{NaCl}, \mathrm{CaCl}_{2}$ & + & - & + & - & - \\
\hline 7 & $\mathrm{~W}, \mathrm{CaCl}_{2}$ & - & + & + & - & - \\
\hline 8 & $\mathrm{NaCl}, \mathrm{W}, \mathrm{CaCl}_{2}$ & + & + & + & - & - \\
\hline 9 & $\mathrm{~K}_{2} \mathrm{HPO}_{4}$ & - & - & - & + & - \\
\hline 10 & $\mathrm{NaCl}, \mathrm{K}_{2} \mathrm{HPO}_{4}$ & + & - & - & + & - \\
\hline 11 & $\mathrm{~W}, \mathrm{~K}_{2} \mathrm{HPO}_{4}$ & - & + & - & + & - \\
\hline 12 & $\mathrm{NaCl}, \mathrm{W}, \mathrm{K}_{2} \mathrm{HPO}_{4}$ & + & + & - & + & - \\
\hline 13 & $\mathrm{CaCl}_{2}, \mathrm{~K}_{2} \mathrm{HPO}_{4}$ & - & - & + & + & - \\
\hline 14 & $\mathrm{NaCl}, \mathrm{CaCl}_{2}, \mathrm{~K}_{2} \mathrm{HPO}_{4}$ & + & - & + & + & - \\
\hline 15 & $\mathrm{~W}, \mathrm{CaCl}_{2}, \mathrm{~K}_{2} \mathrm{HPO}_{4}$ & - & + & + & + & - \\
\hline 16 & $\mathrm{NaCl}, \mathrm{W}, \mathrm{CaCl}_{2}, \mathrm{~K}_{2} \mathrm{HPO}_{4}$ & + & + & + & + & - \\
\hline 17 & $\mathrm{M}$ & - & - & - & - & + \\
\hline 18 & $\mathrm{NaCl}, \mathrm{M}$ & + & - & - & - & + \\
\hline 19 & $\mathrm{~W}, \mathrm{M}$ & - & + & - & - & + \\
\hline 20 & $\mathrm{NaCl}, \mathrm{W}, \mathrm{M}$ & + & + & - & - & + \\
\hline 21 & $\mathrm{CaCl}_{2}, \mathrm{M}$ & - & - & + & - & + \\
\hline 22 & $\mathrm{NaCl}, \mathrm{CaCl}_{2}, \mathrm{M}$ & + & - & + & - & + \\
\hline 23 & $\mathrm{~W}, \mathrm{CaCl}_{2}, \mathrm{M}$ & - & + & + & - & + \\
\hline 24 & $\mathrm{NaCl}, \mathrm{W}, \mathrm{CaCl}_{2}, \mathrm{M}$ & + & + & + & - & + \\
\hline 25 & $\mathrm{~K}_{2} \mathrm{HPO}_{4}, \mathrm{M}$ & - & - & - & + & + \\
\hline 26 & $\mathrm{NaCl}, \mathrm{K}_{2} \mathrm{HPO}_{4}, \mathrm{M}$ & + & - & - & + & + \\
\hline 27 & $\mathrm{~W}, \mathrm{~K}_{2} \mathrm{HPO}_{4}, \mathrm{M}$ & - & + & - & + & + \\
\hline 28 & $\mathrm{NaCl}, \mathrm{W}, \mathrm{K}_{2} \mathrm{HPO}_{4}, \mathrm{M}$ & + & + & - & + & + \\
\hline 29 & $\mathrm{CaCl}_{2}, \mathrm{~K}_{2} \mathrm{HPO}_{4}, \mathrm{M}$ & - & - & + & + & + \\
\hline 30 & $\mathrm{NaCl}, \mathrm{CaCl}_{2}, \mathrm{~K}_{2} \mathrm{HPO}_{4}, \mathrm{M}$ & + & - & + & + & + \\
\hline 31 & $\mathrm{~W}, \mathrm{CaCl}_{2}, \mathrm{~K}_{2} \mathrm{HPO}_{4}, \mathrm{M}$ & - & + & + & + & + \\
\hline 32 & $\mathrm{NaCl}, \mathrm{W}, \mathrm{CaCl}_{2}, \mathrm{~K}_{2} \mathrm{HPO}_{4}, \mathrm{M}$ & + & + & + & + & + \\
\hline
\end{tabular}

$\mathrm{W}=$ Fermentation liquor

$\mathrm{M}=$ Factors appeared to be insignificant in the Plackett \& Burman experiment 
Table 4. Responses and statistical analysis of the $2^{\mathrm{n}}$ factorial experiment with respect to protein production by Dunaliella salina

\begin{tabular}{|c|c|c|c|c|c|}
\hline Trial & Factor(s) under study & 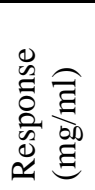 & 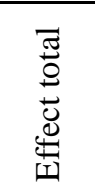 & 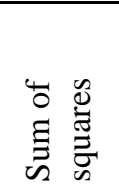 & 胥 \\
\hline 1 & Base & 0.207 & 7.237 & total & \\
\hline 2 & $\mathrm{NaCl}$ & 0.275 & 1.669 & 0.087 & $9.667^{*}$ \\
\hline 3 & $\mathrm{~W}$ & 0.175 & 2.149 & 0.144 & $16.000^{* * *}$ \\
\hline 4 & $\mathrm{NaCl}, \mathrm{W}$ & 0.296 & 0.507 & 0.008 & 0.889 \\
\hline 5 & $\mathrm{CaCl}_{2}$ & 0.118 & -0.017 & $0.9 \times 10^{-5}$ & 0.001 \\
\hline 6 & $\mathrm{NaCl}, \mathrm{CaCl}_{2}$ & 0.154 & -0.477 & 0.007 & 0.778 \\
\hline 7 & $\mathrm{~W}, \mathrm{CaCl}_{2}$ & 0.202 & 0.299 & 0.003 & 0.333 \\
\hline 8 & $\mathrm{NaCl}, \mathrm{W}, \mathrm{CaCl}_{2}$ & 0.280 & -0.339 & 0.004 & \\
\hline 9 & $\mathrm{~K}_{2} \mathrm{HPO}_{4}$ & 0.113 & 0.025 & $0.2 \times 10^{-5}$ & 0.0002 \\
\hline 10 & $\mathrm{NaCl}, \mathrm{K}_{2} \mathrm{HPO}_{4}$ & 0.233 & 0.173 & 0.0009 & 0.100 \\
\hline 11 & $\mathrm{~W}, \mathrm{~K}_{2} \mathrm{HPO}_{4}$ & 0.343 & 0.277 & 0.002 & 0.222 \\
\hline 12 & $\mathrm{NaCl}, \mathrm{W}, \mathrm{K}_{2} \mathrm{HPO}_{4}$ & 0.688 & 0.287 & 0.003 & \\
\hline 13 & $\mathrm{CaCl}_{2}, \mathrm{~K}_{2} \mathrm{HPO}_{4}$ & 0.186 & -0.781 & 0.019 & 2.111 \\
\hline 14 & $\mathrm{NaCl}, \mathrm{CaCl}_{2} \mathrm{~K}_{2} \mathrm{HPO}_{4}$ & 0.228 & -0.421 & 0.006 & \\
\hline 15 & $\mathrm{~W}, \mathrm{CaCl}_{2} \mathrm{~K}_{2} \mathrm{HPO}_{4}$ & 0.159 & -0.989 & 0.031 & \\
\hline 16 & $\mathrm{NaCl}, \mathrm{W}, \mathrm{CaCl}_{2} \mathrm{~K}_{2} \mathrm{HPO}_{4}$ & 0.296 & 0.153 & 0.0007 & \\
\hline 17 & $\mathrm{M}$ & 0.107 & -0.669 & 0.014 & 1.556 \\
\hline 18 & $\mathrm{NaCl}, \mathrm{M}$ & 0.144 & -0.225 & 0.002 & 0.222 \\
\hline 19 & $\mathrm{~W}, \mathrm{M}$ & 0.123 & 0.299 & 0.003 & 0.333 \\
\hline 20 & $\mathrm{NaCl}, \mathrm{W}, \mathrm{M}$ & 0.285 & -0.323 & 0.003 & \\
\hline 21 & $\mathrm{CaCl}_{2}, \mathrm{M}$ & 0.076 & 1.397 & 0.061 & $6.777^{*}$ \\
\hline 22 & $\mathrm{NaCl}, \mathrm{CaCl}_{2}, \mathrm{M}$ & 0.254 & 0.245 & 0.002 & \\
\hline 23 & $\mathrm{~W}, \mathrm{CaCl}_{2}, \mathrm{M}$ & 0.421 & 1.145 & 0.041 & \\
\hline 24 & $\mathrm{NaCl}, \mathrm{W}, \mathrm{CaCl}_{2}, \mathrm{M}$ & 0.489 & -0.057 & 0.0001 & \\
\hline 25 & $\mathrm{~K}_{2} \mathrm{HPO}_{4}, \mathrm{M}$ & 0.086 & -1.053 & 0.035 & 3.888 \\
\hline 26 & $\mathrm{NaCl}, \mathrm{K}_{2} \mathrm{HPO}_{4}, \mathrm{M}$ & 0.186 & -0.509 & 0.008 & \\
\hline 27 & $\mathrm{~W}, \mathrm{~K}_{2} \mathrm{HPO}_{4}, \mathrm{M}$ & 0.123 & -0.777 & 0.019 & \\
\hline 28 & $\mathrm{NaCl}, \mathrm{W}, \mathrm{K}_{2} \mathrm{HPO}_{4}, \mathrm{M}$ & 0.243 & -0.163 & 0.0008 & \\
\hline 29 & $\mathrm{CaCl}_{2} \mathrm{~K}_{2} \mathrm{HPO}_{4}, \mathrm{M}$ & 0.049 & -0.163 & 0.0008 & \\
\hline 30 & $\mathrm{NaCl}, \mathrm{CaCl}_{2} \mathrm{~K}_{2} \mathrm{HPO}_{4}, \mathrm{M}$ & 0.128 & 0.001 & $0.3 \times 10^{-7}$ & \\
\hline 31 & $\mathrm{~W}, \mathrm{CaCl}_{2} \mathrm{~K}_{2} \mathrm{HPO}_{4}, \mathrm{M}$ & 0.217 & 0.741 & 0.017 & \\
\hline 32 & $\mathrm{NaCl}, \mathrm{W}, \mathrm{CaCl}_{2} \mathrm{~K}_{2} \mathrm{HPO}_{4}, \mathrm{M}$ & 0.353 & 0.391 & 0.005 & \\
\hline
\end{tabular}

$\mathrm{W}=$ Fermentation liquor

$\mathrm{M}=$ Factors appeared to be insignificant in the Plackett \& Burman experiment

$F$-ratios for interactions of more than two factors are neglected.

** Highly significant

* Significant 
Natural Byproducts as Nutrient Additives..

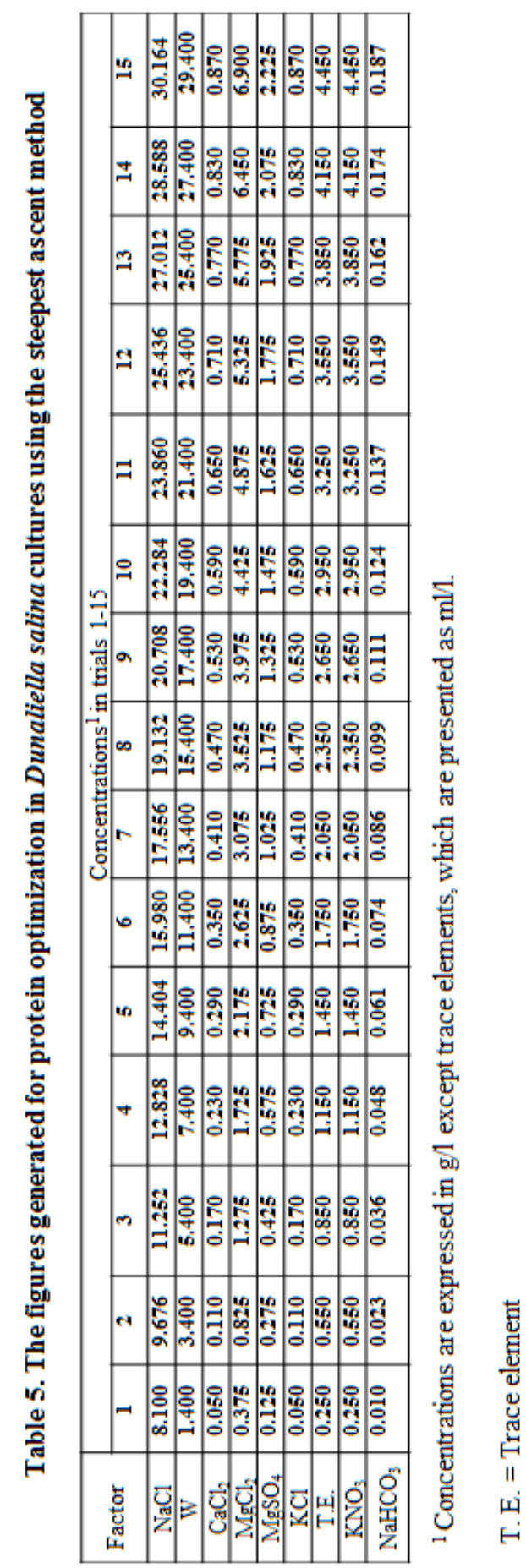




\section{References}

Ben-Amotz, A. and Avron, M. (1980). Glycerol, beta-carotene and dry algal meal production by commercial cultivation of Dunaliella. In G. Shelf and C.J. Soeder (Eds). Algae biomass: Production and Use. Elsevier, Amsterdam, pp. 603-610.

Ben-Amotz, A. and Avron, M. (1983). Accumulation of metabolites by halotolerant algae and its industrial potential. A. Rev. Microbial., 37: 95-119.

Bloor, S. and England, R.R. (1991). Elucidation and optimization of the medium constituents controlling antibiotic production by the cyanobacterium Nostoc muscorum. Enzyme Microb. Technol., 13: 76-81.

Boyd, C. E. (1973). Amino acid composition of fresh water algae. Hydrobiol., 72:19.

Chatfield, C. (1975). Statistics for Technology. Chapman and Hall, London, England, pp. 271-276

Dam, R.; Lee, S.; Fry, P.C. and Fox, H. (1965). Utilization of algae as protein sourcefor humans. J. Nutrition, 86: 376-382.

Fabregas, J.; Herrero, C.; Abalde, J.; Liano, R. and Cabezas, B. (1986). Biomass production and biochemical variability of the marine microalga Dunaliella tertiolecta (Butcher) with high nutrient concentrations. Aquaculture, 53:187-199.

Fabregas, J.; Herrero, C.; Cabezas, B. and Abalde, J. (1985). Mass culture and biochemical variability of the marine microalga Tetraselmis suecica Kylin (Butcher) with high nutrient concentrations. Aquaculture, 49: 231-244.

Ford, T. and Mitchell, R. (1992). Microbial transport of toxic metals. Environ Microbiol, Wiley-Liss, New York, pp. 83-101.

Gerlach, R.F.; De Souza, A.P.; Cury, J.A. and Line, S.R.P. (2000). Effect of lead, cadmium and zinc on the activity of enamel matrix proteinases in vitro. Europ. J. Oral. Sci., 108: 327-334.

Hartree, E.F. (1972). A modification of Lawry method that gives a linear photometric response. Analyt. Biochem., 48: 422.

Johnson, M.; Johnson, J.; MacEllory, R. D.; Speer, H.L. and Bruff,. (1968). Effect of salt on the halophilic alga Dunaliella viridis. Journal of Bacteriology, 95: 1461 - 1468 .

Loeblich, L.A. (1982). Photosynthesis and pigments influenced by light intensity and salinity in the halophilic Danaliella salina (Chlorophyta). J. Mar. Biol. Assoc. UK, 62: 493-508.

Mahasneh, I.A. (1997). Production of single cell protein from five strains of the microalga Chlorella spp. (Chlorophyta). Cytobios, 90 (362-363): 153-161.

Montgomery, C.D. (1991). Design and analysis of experiments. John Wiley \& Sons, Inc, New York.

Myklestad, S. and Haug, A. (1972). Production of carbohydrates by the marine diatom Chaetoceros affinis var. Willei (Gran) Hustedt: I. Effect of the 
concentration of nutrients in the culture medium. J. Exp. Biol. Ecol., 9: 125136.

Orset, S.C. and Young, A.J. (2000). Exposure to low irradiances favors the synthesis of 9-cis beta,beta-carotene in Dunaliella salina. Plant Physiol. (Rockville). 122: 609-617.

Park, D.; Ruy, H.; Lee, K.; Kang, C.; Kim, T. and Lee, H. (1998). The production of hydrocarbons from photoautotrophic growth of Dunaliella salina 1650. In: Appl. Biochem. Biotechnol. Spring, 70-72: 739-746.

Parkinson, G. (1987). New techniques may squeeze more chemicals from algae. Chem. Eng. 94: 19-22.

Parsons, T.R. and Takahashi, M. (1973). Biological Oceanographic Processes. Pergamon Press, New York, NY, pp. 39-49.

Peppler, H.J. (1968). Industrial production of single cell protein from carbohydrates. In R. I. Mateles and R. S. Tannenbaum (Eds). Single cell protein. M.I.T. Press Cambridge, pp. 229-241.

Plackett, R.L. and Burman, J.P. (1946). The design of optimum multifactorial experiments. Biometrika. 33: 305-325

Rivier, J. (1977). Microbial proteins. In M O. Moss and J. E. Smith (Eds). Industrial applications of microbiology. Surrey Univ. Press, pp. 105-149.

Robert, R.L.G. (1979). Growth measurements. Division rate. In R. J. Stein (Ed). Physiological methods. Culture methods and growth measurements. Cambridge Univ. Press, Cambridge, 29: 311.

Schwarz, T.; Bartholmes, P. and Kaufmann, M. (1995). Large-scale production of algal biomass for protein purification: Tryptophan synthase from Euglena gracilis. Biotechnol. Appl. Biochem., 22: 179-190.

Shifrin, N.S. and Chishlom, S.W. (1981). Phytoplankton lipids: Interspecific difference and effects of nitrate, silicate and light-dark cycles. J. Phycol., 17: 374-384.

Shirai, F.; Kunii, K.; Sato, C.; Teramoto, Y.; Mizuki, E.; Murao, S. and Nakayama, S. (1998). Cultivation of microalgae in the solution from the desalting process of soy sauce waste treatment and utilization of the algal biomass for ethanol fermentation. World J. Microbiol.Biotechnol.,14:839842.

Thakur, A.; Kumar, H.D. and Cowsik, S.M. (2000). Effect of pH and inorganic carbon concentration on growth, glycerol production, photosynthesis and dark respiration of Dunaliella salina. In: Cytobios, 102 (400): 69-74.

Thomas, D.E. (1984). Single cell protein. In D. B. Thomas (Eds). Biotechnology. A textbook of industrial microbiology. Wisconsin Univ. Madison U.S.A., pp. 267-275

Yamaoka, Y.; Takimura, O.; Fuse, H. and Kamimura, K. (1994). BetaCarotene production by Dunaliella salina in fed-batch and semi-continuous cultures under nutrient supplement. Seibutsu-Kogaku Kaishi. 72: 111-114. 


\section{استخدام المخلفات الطبيعية كمواد غذائية إضافية للحصول على أعلى دئى محتوى للبروتين في مزرعة طحلب دوناليلا سالينا

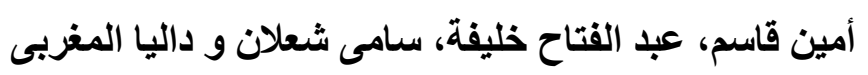 كلية العلوم- قسم النبات- جامعة الأسكثرية}

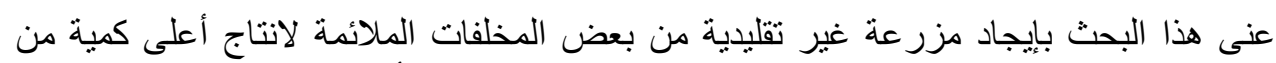

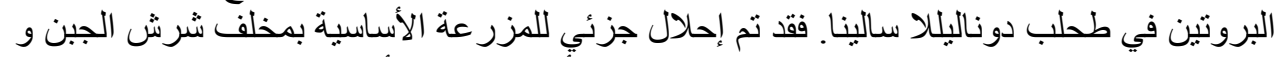

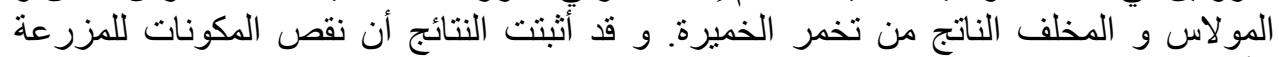

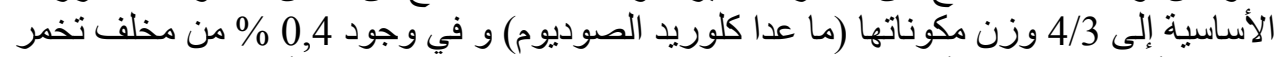

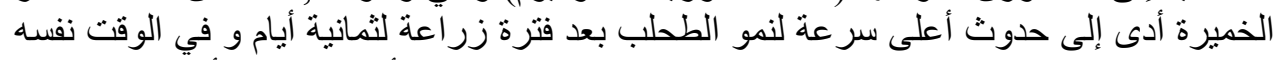

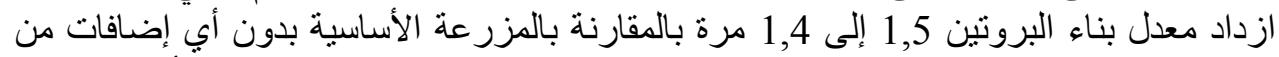

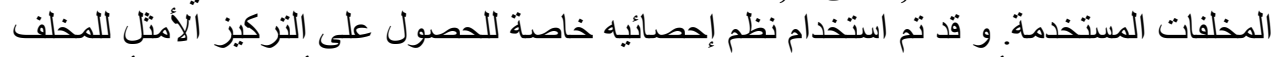

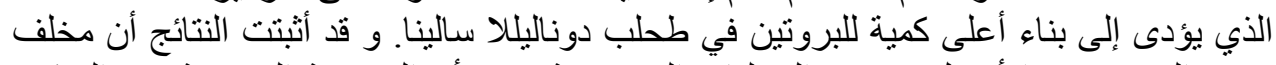

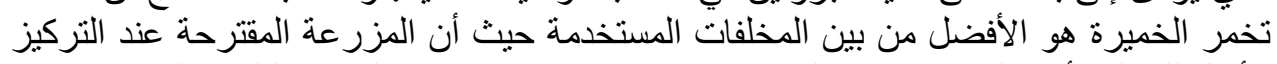
الأمثل للمخلف أدى إلى زيادة بناء البروتين 1,7 مرة في مزر الفئ طحلب دوناليلا سالينا. 